\title{
Pengaruh Penerapan Lembar Kerja Siswa Berbasis Inkuiri Terbimbing Terhadap Kemampuan Metakognisi Siswa Pada Materi Hukum II Newton
}

\author{
L.jianto ${ }^{1^{*}}$, Anita ${ }^{2}$, Boisandi $^{3}$ \\ 1,2,3Prodi Pendidikan Fisika, FMIPATEK IKIP PGRI Pontianak \\ Jl. Ampera No. 88, Pontianak, 78116, Indonesia \\ *Email: ljiantosaputra@yahoo.com
}

Article Info: Submitted: 28/08/2020 | Revised: 20/09/2020 | Accepted: 27/09/2020

\begin{abstract}
Abstrak - Penelitian ini bertujuan untuk mengetahui; (1) kemampuan metakognisi siswa sebelum diterapkan lembar kerja siswa berbasis inkuiri terbimbing pada materi Hukum II Newton, (2) kemampuan metakognisi siswa setelah diterapkan lembar kerja siswa berbasis inkuiri terbimbing pada materi Hukum II Newton, dan (3) seberapa besar pengaruh penerapan lembar kerja siswa berbasis inkuiri terbimbing terhadap kemampuan metakognisi siswa pada materi Hukum II Newton pada kelas X Mia SMA N 1 Marau. Penelitian ini menggunakanpenelitian pre-eksperimental design dengan rancangan penelitian one group pretest-posttest design. Populasi dalam penelitian ini adalah seluruh siswa kelas X SMA N 1 Marau yang terdiri dari 4 kelas. Sampel yang dipilih menggunakan sampel jenuh yaitu kelas X Mia sebagai kelas eksperimen. Hasil penelitian diperoleh sebelum diberikannya perlakuan aspek kemampuan metakognisi siswa yang tinggi yaitu aspek kemampuan pengaturan strategi sebesar $81,81 \%$ dan aspek kemampuan metakognisi yang paling rendah yaitu aspek kemampuan metakognisi strategi debugging sebesar $0 \%$. Sedangkan hasil setelah diberikan perlakuan untuk kemampuan metakognisi siswa yang tinggi yaitu aspek kemampuan pengaturan strategi sebesar 95,23\% dan aspek kemampuan metakognisi yang paling rendah yaitu aspek kemampuan metakognisi strategi debugging sebesar 57,77 \%. Hasil perhitungan Effect size sebesar 5,17 atau 5,17>0,8. Sehingga, pengaruh penerapan LKS berbasis inkuiri terbimbing ini sangat berpengaruh terhadap kemampuan metakognisi siswa.
\end{abstract}

Kata kunci: Lembar kerja siswa, inkuri terbimbing, kemampuan metakognisi, Hukum II Newton

\begin{abstract}
This study aims to determine; (1) students 'metacognition abilities before being applied to guided inquiry-based student worksheets on Newton's Law II material, (2) students' metacognition abilities after being applied guided inquirybased student worksheets on Newton's Law II material, and (3) how much influence is the application of guided inquiry based student worksheets on students' metacognitive abilities in Newton's Law II material in class X Mia SMA N 1 Marau. This research is a pre-experimental research design with one group pretest-posttest design research. The population in this study were all students of class X SMA N 1 Marau which consisted of 4 classes. The sample selected using a saturated sample, namely class X Mia as the experimental class. The results of the study were obtained before the treatment of the aspects of students' high metacognition abilities, namely the aspect of strategy setting ability of $81.81 \%$ and the aspect of the lowest metacognition ability, namely the aspect of metacognition ability of the debugging strategy by $0 \%$. Meanwhile, the results after being given treatment for the students' high metacognition ability were the aspect of strategic setting ability of $95.23 \%$ and the lowest aspect of metacognition ability was the aspect of the metacognition ability of the debugging strategy of 57.77\%. The result of the calculation of the effect size is 5.17 or 5.17>0.8. Thus, the effect of the application of guided inquiry-based worksheets is very influential on students' metacognition abilities.
\end{abstract}

Keywords: student worksheets, guided inquiry, metacognition skills, Newton II Law 


\section{PENDAHULUAN}

Berdasarkan standar kompetensi lulusan tersebut, maka pencapaian kompetensi metakognisi menjadi salah satu tujuan dalam implementasi kurikulum 2013. Metakognisi merupakan salah satu faktor kemampuan kognitif yang berupa berpikir tingkat tinggi dan berpikir kritis mencakup kombinasi antara pemahaman mendalam terhadap topik-topik khusus, kecakapan menggunakan proses kognitif dasar secara efektif, pemahaman dan kontrol terhadap proses kognitif dasar (metakognisi) maupun sikap serta pembawaan [1]. Secara definisi takognitif adalah kemampuan untuk mengontrol ranah atau aspek kognitif. Meta kognitif mengendalikan enam tingkatan aspek kognitif yang didefinisikan oleh Benjamin Bloom dalam taksonomi Bloom yang terdiri dari tahap ingatan, pemahaman, terapan, analisis dan sintetis dan evaluasi [2], [3].

Kemampuan metakognisi mempunyai pengaruh yang sangat besar terhadap hasil belajar dan prestasi akademik siswa. Sebagaimana penelitian yang dilakukan oleh [4], mendapatkan bahwa siswa yang memiliki kemampuan metakognisi yang tinggi, maka rata-rata hasil belajar dan prestasi akademiknya lebih tinggi dari pada siswa dengan kemampuan metakognisi yang rendah. Adapun kajian yang pernah dilakukan terhadap 179 penelitian tentang prestasi belajar, didapatkan bahwa metakognisi menduduki peringkat pertama dari 200 faktor yang mempengaruhi hasil belajar [5].

Kemampuan metakognisi atau berpikir reflektif adalah kemampuan seseorang untuk mereview, memantau dan memonitor proses solusi di dalam pemecahan masalah. Menurut [6] mengajar melalui pemberian masalah memberikan kesempatan untuk siswa membangun konsep mata pelajaran yang diikuti. Supaya dapat menyelesaikan masalah dalam fisika siswa harus melalui proses berpikir saintifik dan erat kaitannya proses berpikir tersebut dengan kemampuan metakognisi siswa.

Untuk menerapkan pembelajaran berbasis penyelidikan tentunya diperlukan suatu media belajar. Salah satu media belajar yang dapat membantu guru dan siswa dalam aktivitas belajar tersebut diantaranya adalah lembar kerja siswa (LKS) [7], [8]. Selain itu, LKS juga dapat digunakan sebagai acuan atau panduan pelaksanaan kegiatan pembelajaran atau sebagai media pembelajaran. Lembar kerja siswa merupakan panduan belajar yang berisi lima bagian diantaranya pengenalan masalah, gagasan awal, eksplorasi, penyamaan materi dan penutup. lembar kerja siswa juga dapat digunakan sebagai pedoman guru dan siswa dalam melaksanakan proses belajar mengajar karena LKS membimbing siswa tentang apa atau bagaimana melakukan aktivitas praktik. Sebagaimana menurut [9], LKS berisi lembar kegiatan siswa dan soal-soal latihan, LKS juga memuat ringkasan materi yang membantu dan mempermudah siswa dalam kegiatan pembelajaran.Berdasarkan pemaparan di atas, penelitian ini bertujuan untuk mengetahui seberapa besar pengaruh penerapan lembar kerja siswa berbasis inkuiri terbimbing terhadap kemampuan metakognisi siswa pada materi Hukum II Newton.

Berdasarkan wawancara di SMA terutama pada guru mata pelajaran fisika dan kelas X Mia, diperoleh informasi pada kenyataannya bahwa ada beberapa sekolah belum menyangkup mengenai kemampuan metakognisi, yaitu kemampuan merencanakan, kemampuan mengelola informasi pengaturan strategi, kemampuan pemantauan pemahaman, kemampuan strategi debugging dan kemampuan mengevaluasi. Sehingga diharapkan hasil belajar meningkat.

Berdasarkan data yang diperoleh, kelas X Mia memiliki rata-rata keseluruhan kemampuan metakognisi tergolong sangat tinggi yakni sebesar 82.04, khususnya pada materi Hukum II Newton. Kemampuan metakognisi anak tidak muncul dengan sendirinya, tetapi memerlukan latihan sehingga menjadi kebiasaan. Berdasarkan pernyataan tersebut maka diperlukan pengelohan proses pembelajaran yang tepat. Sehingga harapannya akan meningkat kemampuan metakognisi dan hasil belajar siswa. Hal ini sesuai dengan Nuvitalia (2014) yang menyatakan bahwa dengan menerapkan metakognisi dapat meningkatkan nalar siswa dengan melibatkan kegiatan langsung.

Adapun tujuan dari penelitian ini untuk mengetahui pengaruh penerapan lembar kerja siswa berbasis inkuiri terbimbing terhadap kemampuan metakognisi siswa pada materi hokum II Newton di kelas X Mia SMA N 1 Marau.

\section{METODE PENELITIAN}

Penelitian ini dilakukan di SMA N 1 Marau pada akhri februari 2020 dengan materi yang diambil pada semester genap yaitu materi Hukum II Newton. Subyek penelitian kelas X Mia, dipilih berdasarkan dengan jenis penelitian yang akan dilakukan. Penelitian ini merupakan penelitian eksperimen 
dengan desain penelitian pre-eksperimental design dan rancangan penelitian menggunakan One group pretest-post-test design [10].

Penelitian ini memberikan pretest dan posttest dalam kegiatan penelitiannya. Penelitian dilakukan dengan memberikan perlakuan kepada kelas X Mia yang akan diteliti berupa penerapan LKS berbasis inkuiri terbimbing sebanyak satu kali pertemuan. Setelah diberikan perlakuan pada kelas X Mia tersebut, kemudian diberikan post-test berupa soal yang memiliki indicator kemampuan metakognisi siswa. Data hasil post-test dianalisis kemudian diambil suatu kesimpulan.

Teknik analisis data yang dilakukan adalah analis data awal dan analisis data akhir. Analisis data tahap awal berupa observasi awal, studi kurikulum SMA, literature lembar kerja siswa berbasis inkuiri terbimbing, literature kemampuan metakognisi serta validasi terhadap seluruh instrument. Analisis data akhir berupa analisis perhitunganrerata skor tes dan persentase indicator kemampuan metakognisi siswa. Data hasil post-test dianalisis sesuai dengan rubric penskoran terhadap kemampuan metakognisi siswa.

\section{HASIL DAN PEMBAHASAN}

Pembelajaran dalam penelitian ini menggunkan LKS berbasis inkuir terbimbing, dimana siswa diberi kesempatan luas dalam melakukan perannya sebagai siswa yaitu menemukan dan memecahkan masalah secara mandiri. Penelitian ini juga merupakan penelitian dasar yang bertujuan untuk memperolh kemmampuan metakgonisi siswa, khususnya pada materi Hukum II Newton. Berdasarkan hasil penelitian diperoleh data kemampuan metakognisi siswa seperti pada Tabel 1.

Tabel 1. Kemampuan metakognisi siswa

\begin{tabular}{lll}
\hline \multicolumn{1}{c}{ Indikator } & Nilai (\%) & \multicolumn{1}{c}{ Kriteria } \\
\hline $\begin{array}{l}\text { Kemampuan } \\
\text { merencanakan }\end{array}$ & 94.54 & Sangat tinggi \\
$\begin{array}{l}\text { Kemampuan pengaturan } \\
\text { strategi }\end{array}$ & 95.23 & Sangat tinggi \\
$\begin{array}{l}\text { Kemampuan pemantauan } \\
\text { pemahaman }\end{array}$ & 76 & Tinggi \\
$\begin{array}{l}\text { Kemampuan strategi } \\
\text { debugging }\end{array}$ & 57.77 & Rendah \\
$\begin{array}{l}\text { Kemampuan mengevaluasi } \\
\text { Rata-rata keseluruhan }\end{array}$ & 86.66 & Sangat tinggi \\
\hline
\end{tabular}

Berdasarkan Tabel 1, untuk setiap indikator metakognisi, tergolong pada kriteria sangat tinggi. Hal ini dikarenakan dalam praktikum, kemampuan metakognisi siswa dilatih untuk berpikir ilmiah, bersiakap ilmiah dengan memberikan kesempatan kepada siswa untuk menuangkan ide-ide yang dimiliki dalam memecahkan permasalahan yang ada [11].

Pada proses kemampuan merencanakan merupakan bagian awal dari aspek kemampuan metakognisi siswa. Dimana siswa diberikan soal yang telah disusun berdasarkan indikaor kemampuan metakognisi siswa. Soal tersebut dapat membantu siswa dalam menentukan sebuah hipotesis dari kasus yang ada. Hal ini sesuai dengan [5], [12] yang menyatakan bahwa dengan menerapkan metakognisi dapat meningkatkan nalar siswa dengan melibatkan kegiatan langsung.

Untuk kemampuan pengaturan strategi, kemampuan metakognisi siswa tergolong sangat tinggi. Dalam hal ini, siswa telah dapat mengaitkan dan menghubungkan soal sebelumnya. Sehingga apabila soal sebelumnya telah dikuasai dan dipahami tentu saja akan mempermudah siswa dalam melanjutkan pengerjaan soal. Dengan demikian hal ini berdampak pada hasil belajar siswa. Hal ini senada dengan [11] yang menyatakan bahwa apabila indicator awal sudah dianggap tuntas maka siswa akan lebih mudah untuk memahami materi pada indicator selanjutnya, dan sebaliknya apabila indicator awal belum dikuasai oleh siswa maka siswa akan lebih sulit dalam memahami indicator berikutnya.

Untuk kemampuan pemantauan pemahaman, kemampuan metakognisi siswanya tergolong tinggi. Hal ini dikarenakan masih banyak siswa yang keliru dalam memahami soal yang diberikan. Sehingga berdapak pada hasil kemampuan strategi debugging, dimana masih tergolong rendah. Hal ini dapat dilihat pada hasil tabel diatas. Sedangkan untuk kemampuan mengevaluasi, kemampuan metakognisi siswa tergolong tinggi. Sehingga untung hasil rata-rata keseluruhan kemampuan metakognisi siswa tergolong sangat tinggi dengan nilai sebesar $82.04 \%$. Hal ini berarti bahwa kemampuan metakognisi yang dimiliki siswa meliputi merencanakan, pengaturan strategi, pemantauan pemahaman, strategi debugging serta kemampuan mengevaluasi sangat tinggi.

Hasil yang sangat tinggi ini diharapkan dapat meningkatkan hasil belajar siswa. Hal ini senada dengan [11] semakin baik kemampuan metakognisi 
yang dimiliki peserta didik maka semakin baik juga hasil belajar yang diperoleh. Ditambahkan [13], bahwa dengan pembelajaran berbasis praktiku dapat menunjang keberhasilan proses pembelajaran, khususnya hasil belajar fisika.

\section{KESIMPULAN}

Berdasarkan hasil penelitian dan analisis data yang dilakukan bahwa secara umum kemampuan metakognisi siswa kelas X Mia SMA N 1 Marau yang mengambil penerapan LKS berbasis inkuiri terbimbing tergolong sangat tinggi yaitu sebesar $82.04 \%$. Sehingga dapat ditarik suatu kesimpulan bahwa penerapan LKS berbasis inkuiri terbimbing terhadap kemampuan metakognisi siswa terdapat pengaruh yang sangat besar. Adapun saran dalam penelitian ini adalah sebagai berikut: guru hendaknya selalu melakukan inovasi dalam pembelajaran untuk meningkatkan kemampuan metakognisi siswa sehingga akan berdampak terhadap hasil belajar siswa yang baik. Penerapan LKS berbasis inkuiri terbimbing ini harapannya harus diterapkan pada materi-materi yang berhubungan dengan pembelajaran Fisika.

\section{DAFTAR PUSTAKA}

[1] T. Djudin, "Using metacognitive strategies to improve reading comprehension and solve a word problem," J. Educ. Teach. Learn., vol. 2, no. 1, pp. 124-129, 2017.

[2] Z. W. Warouw, "Pembelajaran Reciprocal Teaching dan Metakognitif (RTM) yang memberdayakan keterampilan metakognitif dan hasil belajar biologi siswa SMP," J. Ilmu Pendidik., vol. 17, no. 2, 2016.

[3] B. Wicaksono, "Peningkatan Kemampuan Metakognitif Fisika Melalui Model Pembelajaran Problem Based Learning Pada SMK Pancasila 1 Kutoarjo," Radiasi J. Berk. Pendidik. Fis., vol. 3, no. 2, pp. 182-185, 2013.

[4] A. Amzil, "The effect of a metacognitive intervention on college students' reading performance and metacognitive skills," J. Educ. Dev. Psychol., vol. 4, no. 1, p. 27, 2014.

[5] C.-Y. Shen and H.-C. Liu, "Metacognitive skills development: A web-based approach in higher education.," Turk. Online J. Educ. Technol.-TOJET, vol. 10, no. 2, pp. 140-150, 2011.

[6] M. Fitriana and S. Haryani, "Penggunaan Strategi Pembelajaran Inkuiri untuk Meningkatkan
Metakognisi Siswa SMA," J. Inov. Pendidik. Kim., vol. 10, no. 1, 2016.

[7] F. Fitriyati, E. S. Kurniawan, and N. Ngazizah, "Pengembangan LKS Fisika SMA Kelas $X$ Semester II dengan Website Online Berbasis Contextual Teaching Learning," Radiasi J. Berk. Pendidik. Fis., vol. 3, no. 1, pp. 7-11, 2013.

[8] S. Susilawati and I. Ishafit, "Pengembangan LKPD Berbasis Inquiry Learning Berbantuan Media Simulasi dengan Modellus pada Materi Gerak Melingkar Beraturan," Radiasi J. Berk. Pendidik. Fis., vol. 13, no. 1, pp. 29-34, 2020.

[9] L. E. Mandiri, "Pengembangan LKS Fisika SMA Kelas X Semester II Berbasis Web-learning Tanpa Jaringan," Radiasi J. Berk. Pendidik. Fis., vol. 3, no. 1, pp. 12-15, 2013.

[10] A. Suharsimi, "metodelogi Penelitian," Yogyak. Bina Aksara, 2006.

[11] L. R. Nurmalasari, W. Winarso, and E. Nurhayati, "Pengaruh Kemampuan Metakognisi terhadap Hasil Belajar Matematika di SMP Negeri 2 Leuwimunding Kabupaten Majalengka," Nusant. Res., vol. 2, no. 02, pp. 133-147, 2015.

[12] S. L. H. Assagaf, "Analisis Kemampuan Metakognisi Mahasiswa Calon Guru," Vox Edukasi J. Ilm. Ilmu Pendidik., vol. 10, no. 1, pp. 61-65, 2019.

[13] I. Pratiwi, S. Suratno, and M. Iqbal, "Peningkatan Kemampuan Metakognisi dan Hasil Belajar Siswa dengan Pendekatan Keterampilan Proses Melalui Think Pair Share pada Siswa Kelas X-3 SMAN Yosowilangun Lumajang Tahun 2014/2015," J. Edukasi, vol. 3, no. 2, pp. 22-28, 2016. 